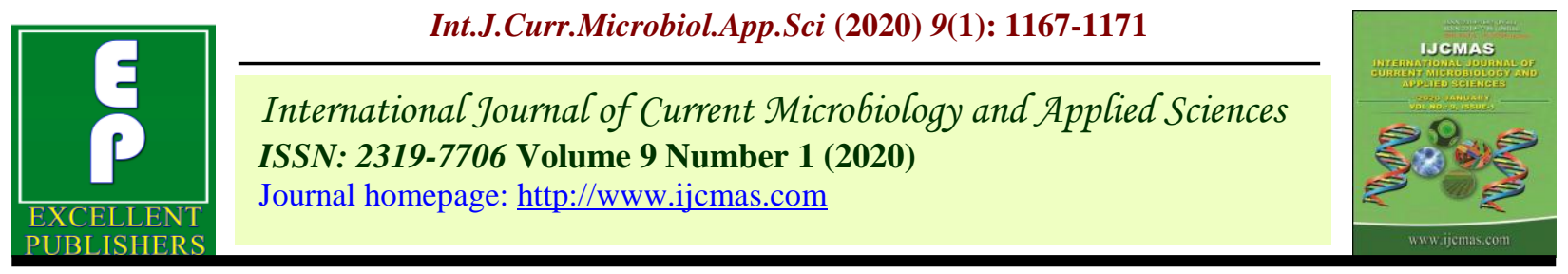

Original Research Article

https://doi.org/10.20546/ijcmas.2020.901.131

\title{
Evaluation of Yard Long Bean (Vigna unguiculata subsp. sesquipedalis (1.) Verdcourt) Genotypes in Vertisols of Andhra Pradesh
}

\author{
C. Sarada* and N. Hari Prasad Rao \\ Hoticultural Researh Station, Lam -DrYSRHU, India \\ *Corresponding author
}

\section{A B S T R A C T}

\section{Keywords}

Yard long bean, (Vigna unguiculata subsp. sesquipedalis (1.) Verdcourt), legume, Vertisols, Andhra Pradesh

Article Info

Accepted:

15 December 2019

Available Online:

20 January 2020
Yard long bean (Vigna unguiculata subsp. sesquipedalis (1.) Verdcourt) is one of the important legume vegetable crop. The present investigation was conducted with an objective to identify the best accessions suitable for Vertisols in Andhra Pradesh. The trial was conducted with six genotypes in RBD with four replications during 2016-18. The data was collected on growth parameters, yield attributes and yield. Among the entries evaluated, VL Lobia-1 recorded significantly maximum plant height, pod length and average pod weight. Pod girth was maximum in Arka Mangala, whereas number of pods per plant was maximum in VS-3. Among the entries evaluated, VS-3 recorded significantly maximum yield $(66.2 \mathrm{q} / \mathrm{h})$ followed by Arka Mangala (54.7q/ha).

\section{Introduction}

Yard long bean (Vigna unguiculata (L.) Walp. subsp. sesquipedalis (l)Verdc) is one of the economically important leguminous vegetable crop. It is generally known as vegetable cowpea. It is also called as Chinese long bean, string bean, snake bean, snap pea with chromosome number $2 n=2 x=22$. This plant is of a different genus from the common bean. It is a vigorous climbing annual vine. It is a variety of the cowpea and grown primarily for its strikingly long (35- to $75-\mathrm{cm}$ ) immature pods and has uses very similar to that of the green bean. The varieties of yard long beans are usually distinguished by the different colors of their mature seeds. The plant attracts many pollinators, specifically various types of yellow jackets and ants. It is a highly selfpollinating annual crop. Natural crossing between plants in a row is less than $1 \%$.The crop is mainly cultivated for its green tender pods for vegetable purpose. It is widely grown in Southeast Asia, South China, Indonesia, Philippines, Taiwan, and Thailand (Rachie, 1985). Now-a-days it is being cultivated in several states of India. It is most extensive cultivated in Kerala, Karnataka, and Maharashtra. However, in AP, it is generally cultivated in isolated pockets and mostly in 
kitchen gardens. In India, it is generally cultivated in an area of 18,560 $-20,160$ ha annually. Being leguminous vegetable, it is generally valued for its nutritive value. It contains a good amount of digestible protein both in pods (23.5 -26.3\%) and in leaves. Yard long beans are a good source of vitamins $A$ and $C$, providing $17 \%$ and $31 \%$ of the recommended daily allowance for these vitamins respectively. It is also rich in calcium $(72.0 \mathrm{mg})$, phosphorus $(59 \mathrm{mg})$, iron $(2.5 \mathrm{mg})$, carotene $(564 \mathrm{mg})$, thiamine $(0.07$ $\mathrm{mg})$, riboflavin $(0.09 \mathrm{mg})$ and vitamin $\mathrm{C}(24$ $\mathrm{mg}$ ) per $100 \mathrm{~g}$ of edible pods. It is also a good source of micronutrients containing 102.69 $120.02 \mathrm{mg} \mathrm{kg}^{-1}$ of iron, $32.58-36.66 \mathrm{mg} \mathrm{kg}^{-1}$ of zinc, $2.92-3.34 \mathrm{mg} \mathrm{kg}^{-1}$ of manganese, and $0.33-0.57 \mathrm{mg} \mathrm{kg}{ }^{-1}$ of cobalt (Ano and Ubochi, 2008). It enriches soil fertility by fixing atmospheric nitrogen. Because of its quick growth habit it has become an essential component of sustainable agriculture in marginal lands of the tropics. It is usually grown intercropped with sorghum or millet and also in rotation cropping system. Optimum average temperature during the growing period is $20^{\circ} \mathrm{C}$ to $30^{\circ} \mathrm{C}$. It prefers full sunshine during growth and development, whereas cloudy and rainy weather cause low yield due to poor fruit set and dropping of young pods. It can be grown in various soil types from sandy loam to clay, but loam and sandy loam with $\mathrm{pH}$ 6.2-7.0 are the best for yard long bean production. Although it is a highly nutritive legume vegetable, commercial cultivation of yard long bean for vegetable purpose was very low. The production and productivity of yard long bean is mainly constrained by low yield, sensitive to adverse climatic conditions and susceptibility to pests and diseases. (Sarutayophat et al., 2007). Yardlong bean varieties with high yield and better pod quality has not been released in Andhra Pradesh till now and no proper research thrust has been given for the improvement of this legume vegetable. Selection of suitable varieties is an important step for successful and economic cultivation of any crop. In view of its nutritive value and being as legume vegetable plays key role in sustainable crop management programme. Hence, promotion of the crop in AP will certainly improve the soil fertility status and nutritional imbalance. At this juncture, identification of high yielding varieties in yard long bean plays essential role in crop improvement. As it is a new cop and the varieties suitable for the state are not standardized, the present study was undertaken with an objective to evaluate the performance of different yard long bean genotypes in Vertisols of AP.

\section{Materials and Methods}

The experiment was conducted in AICRP on vegetable crops at Horticulture Research station, Lam for two years during Kharif season of 2016-18. The experiment was conducted with six yard long bean cultivars viz., PVCP-20 (Panthnagar), Arka Mangala (IIHR), VL-Lobia-1 (VPKAS, Almora), Vyjayanthi, VS-3 and Lola from Vellanikkara. The cultivars were raised in randomized block design with four replications during Kharif season of 2016 -17 and 2017-18. Data on growth parameters, yield attributes and yield was collected during the experimental period every year from five randomly selected plants from each plot. The data was recorded on plant height $(\mathrm{cm})$, days taken for first flowering, days to $50 \%$ flowering, days to first pod harvesting, number of pods per plant, pod length $(\mathrm{cm})$, pod girth $(\mathrm{cm})$,number of seeds per pod, pod yield ( $\mathrm{q} / \mathrm{ha}$ ). The pod yield was recorded at each harvesting time regularly and later the data of different harvestings were added to get the total yield. The average data was analyzed statistically as per Panse and Sukhumi (1985) and pooled data was done as per Gomez and Gomez (1984). 


\section{Results and Discussion}

Analysis of variance (ANOVA) revealed highly significant differences for all the characters studied, indicating wide variability among the accessions for the characters under study (table1). The data pertaining to the performance of yard long bean accessions in relation to different horticultural traits are presented in table 2 and 3. Significant differences were observed among the accessions for the characters studied.

Plant height is an important growth parameter which varies according to the genotype and in the present study, it ranged from $138 \mathrm{~cm}$ to $317.4 \mathrm{~cm}$. Among the entries evaluated, VLLabia -1 recorded significantly maximum plant height $(317.4 \mathrm{~cm})$ being on par with Vyjayanthi $(308 \mathrm{~cm})$. The variation observed in plant height in these genotypes may be due to genetic variation among the accessions. Similar results of variation in plant height was recorded by Litty Varghese and Celine (2015), Saurabh et al., (2018). Number of branches range from 8.2 (lola) to 13.0 (Vyjayanthi). Among the entries, Vyjayanthi recorded significantly more number of branches (13) followed by VL-Lobia-1 (12.2). Similar results of variation in number of branches was reported by Saurabh et al., (2018). Days to flowering, days to $50 \%$ flowering and days to first harvesting are an important traits in selection for earliness in crop improvement programme. In the present study yard long bean genotypes showed differences with respect to these characters. Among the entries, PVCP-20 and VS -3 were earlier to flower; where as Arka Mangala took more number of days for flowering. PVCP-20 came to harvest early, while VL Lobia took more days for harvest. As days to harvest indicate the earliness of the genotype/variety, it can be used in selection of early genotype/variety. This differential performance of genotypes with respect to variation in flowering and harvesting behavior could be attributed to variation in adoptability of genotypes to difference in environment and variation in their intrinsic properties. Similar results of variation in flowering and fruiting behavior was reported by Vidya et al., (2002), Khanpara et al., (2015), Saurabh et al., (2018).

The data pertaining to yield and its attributes was presented in Table.3. The data revealed that, among the accessions, VL Lobia-1 has maximum pod length $(55.7 \mathrm{~cm})$ being on par with Arka Mangala $(54.5 \mathrm{~cm})$, while PVCP-20 had small sized pod $(35.9 \mathrm{~cm})$. Pod girth was maximum in Arka Mangala $(3.6 \mathrm{~cm})$, being on par with Vyjayanthi $(3.4 \mathrm{~cm})$ and Lola $(3.1 \mathrm{~cm})$. Similar results of variation in pod length and girth was reported by Vidya et al., 2002, Saurabh et al., 2018. Number of pods per plant ranged from 33.5 to 61.5. Among the entries, VS-3 recorded significantly more number of pods (61.5) while minimum numbers of pods were recorded in Lola (33.5). Number of seeds per pod ranged from 18.5 (VS-3) to 23.5 (Vyjayanthi). Among the entries, average pod weight was significantly maximum in VL Lobia-1 (14.7gm). Yield is the most important character to be considered for selection of genotype to a particular region. Significant variability among accessions for yield and yield attributes were observed in the present study. Among the entries evaluated, VS-3 recorded significantly maximum yield $(66.2 \mathrm{q} / \mathrm{h})$ followed by Arka Mangala (54.7q/ha). The maximum yield observed in these genotypes may be due to more number of pods per plant. Among the entries evaluated, Lola recorded lowest yield $(34.3 q / h)$. These differences in the yield attribute and yield could be attributed to the variability in the growth parameters of the genotypes. Similar results of variation in yield and its attributes was earlier reported by Litty Varghese and Celine (2015), Vidya et al., 2002, Saurabh et al., 2018. 
Table.1 Analysis of variance for yield and it's component characters in yard long bean

\begin{tabular}{|l|l|c|c|c|}
\hline \multirow{2}{*}{ S. No. } & Name of the Character & \multicolumn{3}{|c|}{ Mean Sum of Squares } \\
\cline { 3 - 5 } & & Replications & Treatments & Error \\
\hline $\mathbf{1}$ & Plant height & 41.5 & 20357.4 & 354.0 \\
\hline $\mathbf{2}$ & No. of branches & 0.8 & 11.4 & 0.6 \\
\hline $\mathbf{3}$ & Days to first flowering & 1.8 & 81.4 & 1.0 \\
\hline $\mathbf{4}$ & Days to 50\% flowering & 1.9 & 7.4 & 0.7 \\
\hline $\mathbf{5}$ & Days to harvest & 1.0 & 4.8 & 0.5 \\
\hline $\mathbf{6}$ & pod length (cm) & 17.3 & 222.8 & 13.9 \\
\hline $\mathbf{7}$ & Pod Girth (Cm) & 0.2 & 0.3 & 0.1 \\
\hline $\mathbf{8}$ & No. of seeds /pod & & 16.5 & 2.5 \\
\hline $\mathbf{9}$ & No. of fruits/pl & 19.7 & 392.7 & 9.7 \\
\hline $\mathbf{1 0}$ & Average pod weight & 16.3 & 541.4 & 11.2 \\
\hline $\mathbf{1 1}$ & Yield (q/h) & & & \\
\hline
\end{tabular}

Table 2: Evaluation of yard long bean genotypes for growth parameters

\begin{tabular}{|l|c|c|c|c|c|}
\hline \multicolumn{1}{|c|}{ Treatment } & $\begin{array}{c}\text { Plant } \\
\text { height }\end{array}$ & $\begin{array}{c}\text { No. of } \\
\text { branches }\end{array}$ & $\begin{array}{c}\text { Days to first } \\
\text { flowering }\end{array}$ & $\begin{array}{c}\text { Days to 50\% } \\
\text { flowering }\end{array}$ & $\begin{array}{c}\text { Days to first } \\
\text { harvest }\end{array}$ \\
\hline PVCP-20 & 138.0 & 10.1 & 38.8 & 57.5 & 61.1 \\
\hline Vyjayanthi & 308.0 & 13.0 & 47.6 & 58.6 & 62.4 \\
\hline Arka mangala & 190.6 & 10.2 & 49.1 & 60.6 & 63.9 \\
\hline VL-Lobia-1 & 317.4 & 12.2 & 41.0 & 60.5 & 64.1 \\
\hline VS-3 & 280.2 & 10.5 & 38.8 & 58.6 & 62.6 \\
\hline Lola & 220.0 & 8.2 & 41.3 & 57.6 & 63.1 \\
\hline C.D. & 28.6 & 1.2 & 1.5 & 1.3 & 1.1 \\
\hline C.V. & 7.8 & 7.1 & 2.3 & 1.5 & 1.1 \\
\hline
\end{tabular}

Table.3 Evaluation of yard long bean genotypes for yield attributes and yield

\begin{tabular}{|l|c|c|c|c|c|c|}
\hline \multicolumn{1}{|c|}{ Treatment } & $\begin{array}{c}\text { Pod } \\
\text { length }\end{array}$ & $\begin{array}{c}\text { Pod } \\
\text { girth }\end{array}$ & $\begin{array}{c}\text { No. of } \\
\text { seeds/ft }\end{array}$ & $\begin{array}{c}\text { No. of } \\
\text { pods/pl }\end{array}$ & $\begin{array}{c}\text { average } \\
\text { pod wt }\end{array}$ & yield/ha \\
\hline PVCP-20 & 35.9 & 3.2 & 19.8 & 41.5 & 9.6 & 44.3 \\
\hline Vyjayanthi & 43.4 & 3.4 & 23.5 & 42.8 & 9.7 & 46.9 \\
\hline Arka Mangala & 54.5 & 3.6 & 18.6 & 40.5 & 12.3 & 54.7 \\
\hline VL-Lobia-1 & 55.7 & 2.8 & 22.4 & 35.9 & 14.7 & 38.0 \\
\hline VS-3 & 49.9 & 3.1 & 18.5 & 61.5 & 12.8 & 66.2 \\
\hline Lola & 45.3 & 3.3 & 20.3 & 33.5 & 11.8 & 34.3 \\
\hline C.D. & 5.7 & 0.4 & 2.4 & 4.7 & 1.4 & 5.1 \\
\hline C.V. & 7.9 & 9.0 & 7.7 & 7.3 & 7.5 & 7.1 \\
\hline
\end{tabular}


It was concluded that, all the characters in the present study, with regard to growth parameters, yield parameters and yield varied significantly. Based on the present investigation it is concluded that the genotype VS - 3 and Arka Mangala were found to be best in terms of maximum plant height, Number of Branches, Days to first and 50\% flowering, Days to first pod picking. Minimum Number of seeds/pod was recorded in genotype VS-3 and Arka Mangala whereas the number of pods were more in VS-3 and Arka Mangala. Among the entries evaluated, significantly maximum pod Yield/ha was recorded in genotype VS-3 and Arka Mangala indicating their adoptability in Vertisols of AP.

\section{References}

Ano, A.O. and Ubochi, C.I. (2008) "Nutrient composition of climbing and prostrate vegetable cowpea accessions." African J. Biotech. 7(20): 3795-3798.

Gomez, K. A. and A. A. Gomez. 1984. "Statistical procedures for agricultural research". A Wiley Interscience Publication, John Wiley and Sons, New York.

Khanpara1 SV, L. L. Jivani, J. H. Vachhani and V. H. Kachhadia 2015 " Genetic variability, heritability and genetic advance studies in Vegetable Cowpea
(Vigna unguiculata (L.) Walp.) " Electronic Journal of Plant Breeding Vol 7 No 2 408-413

Litty Varghese and Celine VA 2015 "Evaluation of yard long bean (Vigna unguiculata subsp. sesquipedalis (1.)Verdcourt) genotypes for yield and quality characters under polyhouse Condition in Kerala" International Journal of Applied And Pure Science and AgricultureVol .1 (7)7-15

Panse, V. G. and Sukhatme, P. V. 1985. "Statistical Methods for Agricultural Workers'. ICAR Publications, New Delhi, India, pp. 359.

Rachie, K. O. 1985. Introduction. In: Singh, S.R., Rachie, K.O. (Eds.), "Cowpea Research, Production, and Utilization". Wiley, Chichester, pp. xxi-xxviii

Sarutayophat, T., Nualsri, C., Santipracha, Q. and Saereeprasert, V. 2007. "Characterization and genetic relatedness among 37 yard long bean and cowpea accessions based on morphological characters and RAPD analysis." Journal of Science and Technology 29: 591-600.

Saurabh Toppo, Devi Singh, Deepanshu 2018 "Evaluation trial on Yard long bean (Vigna Ungiculata SSp Sesquipedalis (L) Verdic in Allahabad agro climatic condition" G J.B.B., VOL.7 (3) 2018: 447-450

\section{How to cite this article:}

Sarada, C. and Hari Prasad Rao, N. 2020. Evaluation of Yard Long Bean (Vigna unguiculata subsp. sesquipedalis (1.) Verdcourt) Genotypes in Vertisols of Andhra Pradesh. Int.J.Curr.Microbiol.App.Sci. 9(01): 1167-1171. doi: https://doi.org/10.20546/ijcmas.2020.901.131 